\title{
Articles
}

\section{Structure and Biological Activity of $\mathrm{K}\left(\mathrm{H}_{2} \mathrm{O}\right) \mathrm{L}$ ( $L=$ 5,7-Dihydroxy-6,4'-dimethoxyisoflavone-3'-sulfonate)}

\author{
Ya-Ning Guo, Xue-Ling Zhang, and Zun-Ting Zhang* \\ School of Chemistry and Materials Science, Shaanxi Normal University, Xi an 710062, P.R. China \\ "E-mail: zhangzt@snmu.edu.cn \\ Received Jume 5, 2006
}

\begin{abstract}
Potassium(I) with 5,7-dihydroxy-6,4'-dimethoxyisoflavone-3'-sulfonate $(\mathrm{L})$ assembles to $\mathrm{K}(\mathrm{H}, \mathrm{O}) \mathrm{L}(\mathrm{L}=5,7-$ dihydroxy-6,4'-dimethoxyisotlavone-3'-sulfonate). It was characterized by single-crystal X-ray diffraction. element analysis, IR and 'H NMR spectroscopy. It crystallizes in the monoclinic space group $P 2 / / n$ and reveals a seven-coordinate complex. Polyhedra potassium chains, $\mathrm{C}-\mathrm{H} \cdots \pi$ and $\mathrm{C}-\mathrm{H} \cdots \mathrm{O}$ and $\mathrm{O}-\mathrm{H} \cdots \mathrm{O}$ hydrogen bonds lead $\mathrm{K}\left(\mathrm{H}_{2} \mathrm{O}\right) \mathrm{L}$ to a three-dimensional network structure. The biological activity of resistance to hypoxia was tested, and the results showed that the biological activity of resistance to hypoxia of $\mathrm{K}\left(\mathrm{H}_{2} \mathrm{O}\right) \mathrm{L}$ is as good as that of its precursor, irisolidone.
\end{abstract}

Key Words : 5,7-Dihydroxy-6,4'-dimethoxyisoflavone-3'-sulfonate, Irisolidone, Crystal structure, Biological activity

\section{Introduction}

Flavonoids and their related compounds are known to exhibit a wide range of interesting biological activities. ${ }^{12}$ Besides the extensive biological activities of flavonoids, this class of compounds exhibits antidiabetic ${ }^{3-5}$ and aldose reductase inhibitory activity. ${ }^{6}$ Irisolidone (5,7-dihydroxy6,4'-dimethoxyisoflavone), a kind of flavonoid, as one of the effective components in the flowers of Pueraia lobata, had the most potent inhibitory activity against Helicobacter pvlori (HP) and reduced the ethanol-induced mortality as well as serum alanine aminotransferase (ALT) and aspartate aminotransferase (AST) activities. ${ }^{8-10}$ Because the solubility of flavonoid is poor, its biological utilization rate is low. Thus, it is necessary to synthesize a water soluble derivative of flavonoid in order to study its possible biological effects. Isoflavonesulfonate occupies an important position in the field of natural products chemistry since they provide a structural link between organic and inorganic components in nature." The pharmacological assay revealed that isoflavonesulfonates enhance antioxidant activity and aldose reductase inhibitory activity as compared with the corresponding parent flavonoids. ${ }^{12-16}$ In our previous works, we have synthesized and studied the crystal structures of many isoflavonesulfonates, ${ }^{17-22}$ especially studied the biological activities of sodium 7,4-dihydroxyisoflavone-3 3 -sulfonate ${ }^{23}$ and sodium 4'-hydroxy-7-methoxyisoflavone-3-sulfonate. ${ }^{2+}$ The results showed that the biological activities of isoflavonesulfonates are better as compared with those of the parent flavonoids. As part of our works, we have synthesized sodium 5,7-dihydroxy-6,4'-dimethoxy-isoflavone-3'sulfonate and reported its crystal structure. ${ }^{25}$ In this paper,<smiles>COc1ccc(-c2coc3cc(O)c(OC)c(O)c3c2=O)cc1[S+](=O)(=O)[O-]</smiles>

Scheme 1

$\mathrm{K}(\mathrm{I})$ with 5,7-dihydroxy-6,4'-dimethoxyisoflavone-3'-sulfonate assembles to $\mathrm{K}\left(\mathrm{H}_{2} \mathrm{O}\right) \mathrm{L}(\mathrm{L}=5,7$-dihydroxy-6,4dimethoxyisoflavone-3'-sulfonate, Scheme 1$). \mathrm{K}\left(\mathrm{H}_{2} \mathrm{O}\right) \mathrm{L}$ was characterized by single-crystal X-ray diffraction, element analysis, IR and ${ }^{1} \mathrm{H} N M R$ spectroscopy. The water-solubility of $\mathrm{K}(\mathrm{H}, \mathrm{O}) \mathrm{L}$ is better than that of irisolidone. Tests on mice show that the biological activity of resistance to hypoxia of $\mathrm{K}\left(\mathrm{H}_{2} \mathrm{O}\right) \mathrm{L}$ is as good as that of its precursor, irisolidone.

\section{Experimental Section}

General methods. Irisolidone (purity $>98.0 \%$ ) was isolated from the flowers of Pueraia lobata and identified by IR and 'H NMR. The chemicals and solvents used in this work were of analytical grade available commercially and were used without further purification. The infrared spectrum was recorded on a Nicollet $170 \mathrm{SX}$ FT-IR spectrophotometer with $\mathrm{KBr}$ pellets in the $4000-500 \mathrm{~cm}^{-1}$ region. The melting point was determined using $\mathrm{X} 4$ melting point instrument (The thermometer had not been emended). The 'H NMR Spectrum was recorded on a Bruker AM-300 spectrometer with TMS as intemal reference and DMSO- $d_{6}$ as solvent. $\mathrm{C}$ and $\mathrm{H}$ contents were analyzed using a PE-2400 
elemental analytic instrument.

Preparation. Irisolidone $(2.0 \mathrm{~g})$ was slowly added to concentrated sulfuric acid $(10 \mathrm{~mL})$ with stirring. The mixture was heated at $40^{\circ} \mathrm{C}$ for $30 \mathrm{~min}$ and cooled to room temperature. It was poured into a saturated $\mathrm{KCl}$ solution $(40$ $\mathrm{mL}$ ) and a yellow precipitate began to appear. After $3 \mathrm{~h}$, the precipitate was filtered and washed with saturated $\mathrm{KCl}$ solution until the $\mathrm{pH}$ value of the filtrate was 7 . The precipitate was recrystallized from water to afford $\mathrm{K}\left(\mathrm{H}_{2} \mathrm{O}\right) \mathrm{L}$ in good yield $(2.5 \mathrm{~g}, 83 \%)$. Yellow plate single crystals suitable for single crystal X-ray diffraction were grown in an ethanol-water $(V: V, 1: 1)$ solution by slow evaporation. m.p.: $299^{\circ} \mathrm{C}$ (decomposed). IR ( $\mathrm{KBr}$ pellet, $\mathrm{cm}^{-1}$ ): 3578 , $3377,2945,1658,1496,1461,1199,1152,1091,1028 . \mathrm{H}$ NMR (DMSO): $\delta 8.41(\mathrm{~s}, 1 \mathrm{H}), 7.89(\mathrm{~d}, J=2.2 \mathrm{~Hz}, 1 \mathrm{H}), 7.50$ (dd, $J=2.2 \mathrm{~Hz}$ and $J=8.6 \mathrm{~Hz}, 1 \mathrm{H}), 7.03(\mathrm{~d}, J=8.6 \mathrm{~Hz}, 1 \mathrm{H})$, $6.55(\mathrm{~s}, \mathrm{IH}), 3.8 \mathrm{I}(\mathrm{s}, 3 \mathrm{H}), 3.62(\mathrm{~s}, 3 \mathrm{H}), 13.05(\mathrm{~s}, 1 \mathrm{H})$ and 10.87 (s, 1H). Anal. Found: C, 45.4; H, 3.1\%. Calcd. For $\mathrm{C}_{17} \mathrm{H}_{15} \mathrm{KO}_{10} \mathrm{~S}: \mathrm{C}, 45.3 ; \mathrm{H}, 3.3 \%$.

$\mathrm{X}$-ray crystallography of complex. Intensities were collected on a Bruker SMART-1000 CCD diffractometer with graphite-monochromated Mo K $\alpha$ radiation $(\lambda=0.71073$ $\AA$ ). Crystal data for the title compound has formula of $\mathrm{C}_{17} \mathrm{H}_{15} \mathrm{KO}_{10} \mathrm{~S}$, monoclinic, space group $\mathrm{P}_{2} / \mathrm{n}$ with $\mathrm{a}=8.348$ (40) $\AA, \mathrm{b}=7.283(30) \AA, \mathrm{c}=30.000(14) \AA, \alpha=\beta=90^{\circ}, \gamma=$ $96.09(7)^{\circ}, Z=4, V=1814(15) \AA^{3}, F(000)=928,4850$ reflections were collected, 3148 of which were used in the refinement to give the final $R 1=0.0777, w R 2=0.1609$. The structure was solved by direct methods and refined by fullmatrix least-squares techniques. All non-hydrogen atoms were assigned anisotropic displacement parameters in the refinement. All hydrogen atoms were added at calculated positions and refined using a riding model. The structure was refined on $F^{2}$ using the SHELXTL-97. ${ }^{26}$ The crystal used for the diffraction study showed no decomposition during data collection. CCDC-233175 contains the supplementary crystallographic data for this paper. These data can be obtained free of charge at www.ccdc.cam.ac.uk/conts/ retrieving.htm] [or from the Cambridge Crystallographic Data Centre (CCDC), 12 Union Road, Cambridge CB2 1EZ, UK; fax: $+44(0)$ 1223-336033; email: deposit(accdc.cam. ac.uk].

Anti-hypoxia activity test. Male and female mice (ICR) weighing from 20 to $22 \mathrm{~g}$ (42-49 days old) were, before experiment, housed for 1 week under conditions customary for animals $\left(20-22{ }^{\circ} \mathrm{C}, 55 \%\right.$ humidity, light/darkness cycle $12 / 12$, commercial feed and water as desired). 48 mice were randomly separated into four groups. Group I received an intraperitoneal injection of sodium carboxymethylcellulose $(0.5 \%)$ only and served as the control; group II received a nimodipine in sodium carboxymethylcellulose $(0.5 \%), 120$ $\mathrm{mg} \cdot \mathrm{kg}^{-1} \cdot \mathrm{d}^{-1}$ and nimodipine was used as the reference drug; and group III received an injection of irisolidone in sodium carboxymethylcellulose $(0.5 \%), 150 \mathrm{mg} \mathrm{kg}^{-1} \cdot \mathrm{d}^{-1}$; group IV received an injection of $\mathrm{K}\left(\mathrm{H}_{2} \mathrm{O}\right) \mathrm{L}$ in sodjum carboxymethylcellulose $(0.5 \%), 150 \mathrm{mg} \cdot \mathrm{kg}^{-1} \cdot \mathrm{d}^{-1}$. Continue to administer 7 days, behavioral tests of resistance to hypoxia were started

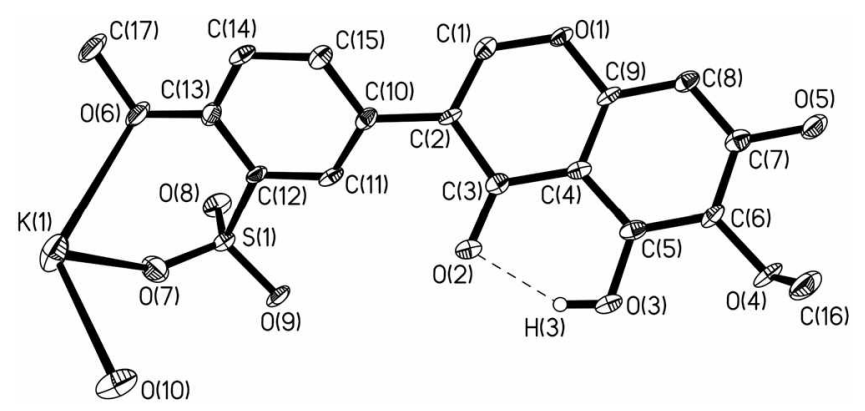

Figure 1. ORTLP drawing ( $40 \%$ probability level) of $\mathrm{K}\left(\mathrm{H}_{2} \mathrm{O}\right) \mathrm{L}$. Thin dashed line indicates the $\mathrm{O}-\mathrm{H} \cdots \mathrm{O}$ intramolecular hydrogen bond. Some $H$ atoms have been omitted for clarity. Selected distances $(\AA)$ and bond angles (deg): $K(1)-O(10), 2.690(13) ; K(1)-$ $\mathrm{O}(7), 2.706(12) ; \mathrm{K}(1)-\mathrm{O}(6), 3.147(10) ; \mathrm{O}(7)-\mathrm{S}(1), 1.438(6) ; \mathrm{O}(8)$ $\mathrm{S}(1), 1.452(6) ; O(9)-\mathrm{S}(1), 1.442(7) ; O(10)-\mathrm{K}(1)-O(7), 90.5(3)$; $O(10)-\mathrm{K}(1)-O(6), 130.4(2) ; O(7)-\mathrm{K}(1)-O(6), 58.9(2) ; O(7)-\mathrm{S}(1)-$ $O(9), 112.0(3) ; \mathrm{O}(7)-\mathrm{S}(1)-\mathrm{O}(8), 112.6(3) ; \mathrm{O}(9)-\mathrm{S}(1)-\mathrm{O}(8), 112.3(4)$.

60 min after the mice received a dose of the compounds to be tested by the intraperitoneal injection last time. Survival time was measured when mice were killed by cervical dislocation immediately.

\section{Results and Discussion}

Crystal structure description. The molecular structure of the title complex is given in Figure 1. 5,7-dihydroxy-6,4'dimethoxyisoflavone-3'-sulfonate anion is the ligand of $\mathrm{K}\left(\mathrm{H}_{2} \mathrm{O}\right) \mathrm{L}$. The anion composed of a benzopyranone moiety $\mathrm{A}[\mathrm{C}(1)-\mathrm{C}(6)] \mathrm{C}[\mathrm{O}(1) / \mathrm{C}(1) / \mathrm{C}(6)-\mathrm{C}(9)]$, a pheny] moiety $\mathrm{B}$ $[\mathrm{C}(10)-\mathrm{C}(15)]$ and a sulfonate monoanion. In the ligand, the bond lengths and bond angles of isoflavone skeleton are agreement with those of $\mathrm{Na}\left(\mathrm{H}_{2} \mathrm{O}\right) \mathrm{L} \cdot 2 \mathrm{H}_{2} \mathrm{O}{ }^{25}$ The benzopyranone moiety is nearly planar and the mean deviation of the atoms from the least-squares plane is $0.0246 \AA$. To avoid steric conflicts, the two rigid ring systems, phenyl ring and benzopyranone moiety are rotated by $39.9^{\circ}$, with respect to each other. The similar S-O bond distances and $\mathrm{O}-\mathrm{S}-\mathrm{O}$ bond angles involving $O(7), O(8)$ and $O(9)$, indicated that the negative charge is delocalized over all three oxygen atoms. In the ligand, the $\mathrm{O} 2 \cdots \mathrm{H} 3$ distance of $1.846 \AA$ clearly shows a strong intramolecular hydrogen bonding. Atoms $\mathrm{O} 2, \mathrm{O} 3$, $\mathrm{C} 3, \mathrm{C} 4, \mathrm{C} 5$ and $\mathrm{H} 3$ are almost planar with a mean deviation to the least square plane of $0.0088 \AA$, which generate a characteristic intramolecular synthon, $S(6)$ motif.

In the crystal structure of $\mathrm{K}\left(\mathrm{H}_{2} \mathrm{O}\right) \mathrm{L}$, the $\mathrm{K}(\mathrm{I})$ is coordinated by seven oxygen atoms, i.e. $\mathrm{O}(\mathrm{I} 0)$ from water molecule, $O(6)$ and $O(6)^{41}$ (Symmetry code: ${ }^{41}-x+1 / 2, y-1 / 2$, $-z^{+1 / 2)}$ from methoxyl group at $\mathrm{C}(13)$, and the other four oxygen atoms from the sulfate monoanion $[O(7)$, $O(7)^{41}, O(8)^{41}$ and $\left.O(8)^{42}\right]$ (Symmetry code: ${ }^{42} \mathrm{x}, \mathrm{y}-1, \mathrm{z}$ ). $\mathrm{Na}\left(\mathrm{H}_{2} \mathrm{O}\right) \mathrm{L} \cdot 2 \mathrm{H}_{2} \mathrm{O}$ and $\mathrm{K}\left(\mathrm{H}_{2} \mathrm{O}\right) \mathrm{L}$ differ in the coordination number ( 6 versus 7$)$. The $\mathrm{K}-\mathrm{O}$ bond lengths fall in the range of $2.690(13)-3.147(10) \AA$, the K-O average distance $(2.877$ $\AA)$ is agreement with that of $\left[\mathrm{K}(\mathrm{HTNR})\left(\mathrm{H}_{2} \mathrm{O}\right)\right]_{\mathrm{n}}(2.864 \AA)^{27}$ and dibenzo-30-crown-10-KI $(2.881 \AA){ }^{28}$ Two adjacent 




Figure 2. Representation of the sheet looking down $a$-axis in $\mathrm{K}\left(\mathrm{H}_{2} \mathrm{O}\right) \mathrm{L}$ by combination of $\mathrm{C}-\mathrm{H} \cdots \pi$ (arene) hydrogen bonds and the ionic chains. Some $\mathrm{H}$ atoms have been omitted for clarity [Symmetry code: $\# 4,1-\mathrm{x},-\mathrm{y}, 1-\mathrm{z}$ ].

potassium nuclei $\left(\mathrm{KI}\right.$ and $\mathrm{K} 1^{43}$ ) (Symmetry code: ${ }^{43}-\mathrm{x}+1 / 2$, $\mathrm{y}+1 / 2,-\mathrm{z}+1 / 2)$ are separated by $4.251 \AA$ and are bridged by $O(6), O(7)$ and $O(8)^{+1}$ to form a polyhedra potassium chain running in $b$-axis. As shown in Figure 2, the isoflavone skeletons are outstretched from the polyhedra potassium chain and arranged in an antiparallel fashion. Pairs of isoflavone skeleton exist four $\mathrm{C}-\mathrm{H} \cdots \pi$ (arene) hydrogen bonds, which make the isoflavone skeletons form a column along the $b$-axis. Atoms $\mathrm{C}(14), \mathrm{C}(15)$ in the molecule at $(\mathrm{x}$, $\mathrm{y}, \mathrm{z})$ act as hydrogen-bond donors, via the atoms $\mathrm{H}(14)$, $\mathrm{H}(15)$ to the $\mathrm{CgA}^{44}, \operatorname{CgC}^{H 4}$ (Symmetry code: ${ }^{44} \mathrm{I}-\mathrm{x},-\mathrm{y}, 1-\mathrm{z}$ ), to form $\mathrm{C}-\mathrm{H} \cdots \pi$ (arene) hydrogen bonds, where $\mathrm{CgA}$ and $\mathrm{CgC}$ are the centers of ring $\mathrm{A}$ and ring $\mathrm{C}$ in the molecule at $(\mathrm{I}-\mathrm{x},-\mathrm{y}, \mathrm{I}-\mathrm{z})$, respectively. The distances of $\mathrm{H}(14) \cdots \mathrm{CgA}^{\mathrm{in}}$ $(2.955 \AA)$. and $\mathrm{H}(15) \cdots \mathrm{CgC}^{44}(2.668 \AA)$ lie in the normal range $(<3.05 \AA)$ of $\mathrm{C}-\mathrm{H} \cdots \pi$ hydrogen bonds. ${ }^{29,30}$ The polyhedral potassium chains and the columns link the molecules into a [ $\overline{1} 01]$ sheet. In the crystal structures of $\mathrm{Na}\left(\mathrm{H}_{2} \mathrm{O}\right) \mathrm{L} \cdot 2 \mathrm{H}_{2} \mathrm{O}$ and $\mathrm{K}\left(\mathrm{H}_{2} \mathrm{O}\right) \mathrm{L}$, sheets are all linked through 5,7-dihydroxy-6,4'-dimethoxyisoflavone-3'-sulfonate (organic moieties) and ploy ion chains which formed by the coordination of metals and oxygen atoms.

It is intriguing that the water molecule in $\mathrm{K}\left(\mathrm{H}_{2} \mathrm{O}\right) \mathrm{L}$ is not only coordinated to the potassium atom, but also donates protons to form intermolecular bonds, $O(10)-\mathrm{H}(10 \mathrm{~A}) \cdots$ $\mathrm{O}(9)^{42}$ and $\mathrm{O}(10)-\mathrm{H}(10 \mathrm{~B}) \cdots \mathrm{O}(9)^{45}$ (Symmetry code: ${ }^{45} 1.5-\mathrm{x}$, $y-0.5,0.5-z)$. The combination of them as well as $O(5)-$ $\mathrm{H}(5) \cdots \mathrm{O}(9)^{46}$ (Symmetry code: $\left.{ }^{46} 2-\mathrm{x}, \mathrm{I}-\mathrm{y}, \mathrm{I}-\mathrm{z}\right), \mathrm{C}(1 \mathrm{l})-$ $\mathrm{H}(11) \cdots \mathrm{O}(4)^{46}$ and $\mathrm{C}(\mathrm{I})-\mathrm{H}(1) \cdots \mathrm{O}(3)^{47}$ (Symmetry code: ${ }^{: 77} \mathrm{x}-1$, $\mathrm{y}, \mathrm{z}$ ) link the sheets to assemble a three-dimensional network structure.

Testing of biological activity against hypoxia in ICR mice. After killed by cervical dislocation, blood supply of mice brain terminated immediately. At short notice, intrinsic blood and nutrient matter of mice brain can maintain brain function, mice dehisce to gasp regularly. Ordinary medicines reduce oxygen consumption of brain all can prolong gasp time of mice. As shown in Table 1, biological tests reported that both irisolidone and the title compound can delay the death of mice effectively. The biological activity of
Table 1. The biological activity of resistance to hypoxia for $\mathrm{K}\left(\mathrm{H}_{2} \mathrm{O}\right) \mathrm{L}$ in ICR mice ( $\left.\overline{\mathrm{x}} \pm \mathrm{s}, \mathrm{n}=12\right)$

\begin{tabular}{lcc}
\hline \multicolumn{1}{c}{ Group } & Dosage $\left(\mathrm{mg}^{\mathrm{kg}} \mathrm{kg}^{-1} \cdot \mathrm{d}^{-1}\right)$ & Survival Time (s) \\
\hline Blank control & - & $20.28 \pm 1.96$ \\
Nimodipine & 120 & $23.45 \pm 1.89^{2 *}$ \\
Irisolidone & 150 & $22.37 \pm 1.68^{*}$ \\
$\mathrm{~K}\left(\mathrm{H}_{2} \mathrm{O}\right) \mathrm{L}$ & 150 & $23.67 \pm 2.50^{*}$ \\
\hline
\end{tabular}

As compared to model group: ${ }^{\mathrm{T}} \mathrm{P}<0.05,{ }^{*+1} \mathrm{P}<0.01$.

resistance to hypoxia of title compound is as good as that of irisolidone and nimodipine.

In conclusion, 5,7-dihydroxy-6,4'-dimethoxyisoflavone3 -sulfonate reacts with the potassium(I) ion to give the complex $\mathrm{K}\left(\mathrm{H}_{2} \mathrm{O}\right) \mathrm{L}$, which shows interesting structural aspects. There are ionic chains, $\mathrm{C}-\mathrm{H} \cdots \mathrm{O}, \mathrm{O}-\mathrm{H} \cdots \mathrm{O}$ intermolecular hydrogen bonds existing in $\mathrm{Na}\left(\mathrm{H}_{2} \mathrm{O}\right) \mathrm{L} \cdot 2 \mathrm{H}_{2} \mathrm{O}$ or $\mathrm{K}\left(\mathrm{H}_{2} \mathrm{O}\right) \mathrm{L}$. In addition, $\mathrm{C}-\mathrm{H} \cdots \pi$ (arene) hydrogen bonds exist in the title compound. The coordination modes oxygen atoms around the potassium atom, the hydrogen bonds and the electrostatic interaction between the cation and the anion sulfonate $\mathrm{L}^{-}$ assemble $\mathrm{K}\left(\mathrm{H}_{2} \mathrm{O}\right) \mathrm{L}$ into supramolecule of a three-dimensional network structure. The water-solubility of $\mathrm{K}\left(\mathrm{H}_{2} \mathrm{O}\right) \mathrm{L}$ is better than that of irisolidone. Tests on mice show that the biological activity of resistance to hypoxia of $\mathrm{K}\left(\mathrm{H}_{2} \mathrm{O}\right) \mathrm{L}$ is as good as that of its precursor, irisolidone.

\section{References}

I. Agullo, G.; Gamet-Payrastre, L.; Manenti, S.; Viala, C.; Remesy, C. Chap, H.; Payrastre, B. Biochem. Pharnocol. 1997, 53, 1649.

2. Wang, I. K.; Lin-Shiau, S. Y.; Lin, J. K. Etr. J. Cancer. 1999, 35 , 1517.

3. Basnet, P.; Kadota, S.; Shimizu, M.; Xu, H. X.; Namba, T. Chem. Pharm. Bull. 1993, 4I, 1790.

4. Hii, C. S. T.; Howell, S. L. J. Endocrinol, 1985, 107 , I.

5. Ragunathan, V.; Sulochana. N. J. Indian Chem. Soc. 1994, 7I, 705 .

6. Aida, K.; Tawata, M.; Shindo, S.; Onaya, T.; Sasaki, H.; Yamaguchi, T. Plama Med. 1990, 56, 254.

7. Kim, D. H.; Yu, K. H.; Bae, E. A.; Han, M. J. Biological and Pharmaceutical Bulletin 1998, 21,628. 
8. Han, Y. O.; Han, M. J.; Park, S. H.; Kim, D. H. J. Pharmacol Sci. $2003,93,331$.

9. Yamazaki, T.; Nakajima, Y;; Niho, Y.; Hosono, T.; Kurashige, T.; Kinjo, J.; Nohara, T. J. Pharm. Phammacol. 1997, 49(8), 831.

10. Yamazaki, T.; Hosono, T.; Matsushita, Y.; Kawashima, K.; Someya, M.; Nakajima, Y.; Narui, K.; Hibi, Y.; Ishizaki, M.; Kinjo, J.: Nohara, T. Int. J. Clin. Pharmacol Res, 2002, 22(1), 23.

II. Wang, X. B.; Zhang, Z. T.; Wang, Q. Y. Strtctural Chemistry $2005,16(5), 461$.

12. Akira, Y.; Takatoshi, U.; Nobuyuki, O.; Hiroyuki, H.; Tomoko, I.; Kensuke, H. Phytochemisty 1988, 35,885 .

13. Hiroyuki, H.; Isao, O.; Sachiko, S.; Ayumi, F. J. Nat. Prod. 1996, $59,443$.

14. Jiang, R. W.; He, Z. D.; Chen, Y. M. Chent. Pharn. Bull. 2001, 49, 1166.

15. Qian, M. K. Acta Chim. Sinica. 1978, 36, 199 (in Chinese).

16. Chen, W. Y. Acta Pham Sin. 1979, 14, 277 (in Chinese).

17. Zhang, Z. T.; Wang, Q. Y. Stnzctural Chemistry 2005, 16(4), 415.

18. Zhang, Z. T.; Wang, Q. Y. Journal of Chemical Cnostallography 2005, 35(9), 679 .

19. Wang, X. B.; Zhang, Z. T.; Wang, Q. Y. Strtctural Chemistry
$2005,16(4), 383$.

20. Wang, X. B.; Zhang. Z. T. Z. Kristallogr. NCS. 2005, 220, 223.

21. Wang, Q. Y.; Zhang, Z. T. Acta Crystallog. Aphica Section C. Crystal Stricture Communications 2005, C61, $\mathrm{m} 215$.

22. Wang, X. B.; Zhang, Z. T.; Wang, Q. Y. Strncture Chemistry 2005, $16(5), 461$.

23. Liu, Q. G; Zhang. Z. T.; Xue, D. Chen. J. Chin. Uni: 2003, 24. 820.

24. Zhang, Z. T.; Liu, Q. G.; Liu, X. H. Acta Chimica Sinica. 2002,60, 1846.

25. Zhang, Z. T.; Guo, Y. N.; Liu, Q. G Chin. J. Chem. 2004, 22, 971.

26. Sheldrick, G. M. SHELIS97. Program Package for Crystal Structure Solution and Refinement; University of Göttingen: Germany, 1997.

27. Li, Y. F.; Zhang, T. L.; Zhang, J. G.; Ma. G. X.; Song, J. C.; Yu, K. B. Acta Chim. Sicina. 2003, 6/(7), 1020.

28. Bush, M. A.; Truter, M. R. J. Chem. Soc., Perkin Trans. 1972, 2, 345.

29. Nishio, M. Cryst. Eng. Conm. 2004, 6(27), 138.

30. Bogdanović, G. A.; Medaković, V;; Milcić, M. K.; Zarić, S. D. Int. J. Mol. Sci. 2004, 5, 176. 